\title{
IMPLEMENTASI PMRI DENGAN ASESMEN PORTOFOLIO UNTUK MENINGKATKAN SIKAP POSITIF TERHADAP MATEMATIKA DAN MOTIVASI BELAJAR
}

\author{
IMPLEMENTATION OF IRME WITH PORTFOLIO ASSESMENT \\ TO IMPROVE STUDENT' POSITIVE ATTITUDE TOWARD MATHEMATICS \\ AND LEARNING MOTIVATION
}

\author{
Ida Nurmila Isandespha, Suwarjo \\ PGSD Universitas Ahmad Dahlan, Universitas Negeri Yogyakarta \\ idapgsd@gmail.com, suwarjo@uny.ac.id
}

\begin{abstract}
Abstrak
Penelitian ini bertujuan untuk meningkatkan sikap positif terhadap matematika dan motivasi belajar siswa kelas melalui PMRI dengan asesmen portofolio. Penelitian ini adalah Penelitian Tindakan Kelas kolaboratif dengan guru kelas sebagai kolaborator pelaksana tindakan. Teknik pengumpulan data meliputi skala sikap siswa, wawancara, dan observasi. Instrumen yang digunakan adalah skala sikap siswa, pedoman wawancara, dan lembar observasi. Analisis data dilakukan dengan analisis kualitatif dan kuantitatif. Hasil penelitian menunjukkan bahwa sikap positif terhadap matematika dan motivasi belajar siswa mengalami peningkatan setelah dilaksanakan tindakan pembelajaran melalui pendekatan PMRI dengan asesmen portofolio. Skor sikap siswa sebelum tindakan adalah 76,50 dengan kriteria cukup positif meningkat menjadi 81,50 dengan kriteria positif pada siklus I dan meningkat lagi menjadi 86,79 dengan kriteria positif pada siklus II. Dari hasil wawancara diperoleh informasi bahwa siswa yang termotivasi untuk belajar lebih giat sebanyak $7,14 \%$ pada pra tindakan, kemudian meningkat menjadi 50\% pada siklus I, dan meningkat lagi menjadi $92,86 \%$ pada siklus II.
\end{abstract}

Kata kunci: PMRI, Portofolio, Sikap positif, Motivasi

\section{Abstract}

This study aim to improve the positive attitudes toward mathematics and learning motivation through Indonesia Realistic Mathematics Education (IRME) with portfolio assessment in mathematics learning. This was a collaborative classroom action research (CAR). The research collaborator was the Grade IV teacher as the action doer. The data were collected through students' attitude scales, interviews, and observation. The instrument included students' attitude scales, interview guided, and observation sheets. The data were qualitatively and quantitatively analyzed. The results of the study showed that the students' positive attitudes toward mathematics and learning motivation improved after the learning actions using the IRME with portfolio assessment. The mean score before the actions was 76.50, indicating a moderately positive criterion. In Cycle I, it improved to 81.50, indicating a positive criterion, and Cycle II it improved to 86.79, indicating a positive criterion. From the interview obtained information that the students who motivated to study harder was $7.14 \%$ in the preaction, 50\% in Cycle, I and improved to $92.86 \%$ in Cycle II.

Keywords: IRME, Portfolios, Positive attitudes, Motivation 


\section{Pendahuluan}

Pendidikan di Sekolah Dasar (SD) dimaksudkan untuk memberikan bekal kemampuan dasar kepada anak didik berupa pengetahuan, keterampilan, dan sikap dan mempersiapkan mereka melanjutkan ke jenjang pendidikan Sekolah Menengah Pertama (SMP). Berdasarkan tujuan institusional pendidikan SD bertugas untuk menyiapkan lulusannya agar siap melanjutkan ke jenjang pendidikan selanjutnya yaitu SMP. Akan tetapi tujuan pendidikan SD dikatakan berhasil apabila siswa mampu mengaplikasikan pengetahuan dan keterampilan yang telah dipelajari di dalam kehidupan sehari-harinya sehingga bisa hidup mandiri dan tidak sepenuhnya tergantung pada pendampingan orang dewasa.

Menurut Djohar (2009, p.166) pendidikan di Indonesia pada kenyataannya masih berorientasi pada empat hal yaitu: (1) pendidikan yang berorientasi tekstual; (2) tidak menyentuh pemberdayaan fisik, akal, dan hati; (3) pendidikan yang menjauh dari kenyataan; dan (4) pendidikan yang menjauh dari lingkungan nyata. Mengenai belajar Duwey (1997, p.73) mengemukakan "anything which called a study, weather arithmetic, history, geography, or one of the natural sciences, must be derived from materials which at the outset fall within the scope of ordinary life-experience". Belajar harus dimulai dari fakta dan kebenaran yang ada di ruang lingkup pengalaman siswa. Sekolah sebagai tempat belajar bagi siswa seharusnya menjadi tempat yang paling bisa memfasilitasi siswa untuk belajar. Sekolah harus dirancang sedemikian rupa sehingga menjadi tempat belajar yang memiliki hubungan erat dengan lingkungan.

Berdasarkan hasil studi awal didapatkan informasi bahwa di SD Muhammadiyah Jogodayoh belum memanfaatkan lingkungan sebagai sumber belajar siswa. SD Muhammadiyah Jogodayoh memiliki halaman sekolah yang luas, akan tetapi pembelajaran cenderung berlangsung di dalam kelas. Halaman sekolah sebagai tempat belajar hanya saat pelajaran olahraga. Tidak mengherankan jika bel istirahat berbunyi anak-anak langsung menghambur keluar kelas dan tak sabar bermain-main di halaman sekolah.

Guru seharusnya memberikan Pekerjaan Rumah (PR) yang lebih dekat dengan aktivitas di rumah sehingga siswa merasa termotivasi untuk mengerjakannya. Seperti,
"Coba tanyakan kepada ibu berapa ons ibu menanak nasi setiap harinya? Sebelum menanak nasi coba timbanglah terlebih dahulu berapa ons tepatnya ibu menanak nasi!". Jadi, berapa kg beras yang dihabiskan ibu selama satu minggu? Dari sini pelajaran matematika sangat dekat dengan kehidupan sehari-hari, dekat dengan lingkungan, bermakna dan menyenangkan.

Dari hasil observasi yang dilaksanakan di kelas IV SD Muhammadiyah Jogodayoh guru memberikan PR berupa soal-soal yang ada di dalam buku acuan dan tidak kontekstual. Masih ada sekitar 6 dari 14 siswa yang sering tidak mengerjakan PR. Dari hasil wawancara beberapa siswa mengaku mengerjakan PR karena takut terkena hukuman dari guru. Apabila siswa tidak mengerjakan PR guru meminta siswa untuk mengerjakan PR di luar kelas atau saat istirahat sehingga siswa merasa sedih kehilangan waktu istirahatnya. Siswa juga malas mengerjakan soal matematika yang sulit. Kondisi ini menunjukkan bahwa motivasi siswa dalam belajar matematika masih rendah. Siswa malas mengerjakan tugas, malas belajar, rasa ingin tahu yang rendah, tidak peduli apabila mendapat nilai rendah, tidak bersemangat dalam belajar merupakan ciri-ciri rendahnya motivasi belajar siswa.

Berdasarkan observasi di kelas IV SD Muhammadiyah Jogodayoh, pembelajaran matematika disampaikan terpisah dengan kehidupan sehari-hari siswa. Pada saat siswa belajar sifat-sifat operasi hitung guru langsung memberikan contoh dari setiap sifat operasi hitung. Guru seharusnya membimbing siswa untuk mengkontruksi sendiri pengetahuannya. Saat mengajar guru menyampaikan materi sesuai dengan buku paket, menjelaskan konsepkonsep matematika seperti yang ada di buku kemudian memberi contoh soal dan memberikan latihan kepada siswa. Guru tidak melakukan pengajaran bermakna dengan menggunakan metode pengajaran yang kurang variatif dan terkesan membosankan. Akibatnya, motivasi belajar siswa sulit ditumbuhkan dan pola belajarnya cenderung menghafal. Menurut Wadsworth (Paul Suparno 2001, p.141), mengingat dan menghafal tidak dianggap sebagai belajar yang sesungguhnya karena kegiatan tersebut tidak memasukkan proses asimilasi dan pemahaman.

Dalam mengerjakan latihan siswa bergantung pada satu jawaban yang benar dan belum diberi kesempatan untuk menyampaikan 
ide atau strategi mereka. Ketika ditanya ternyata beberapa siswa tidak mengerti dengan konsep yang disampaikan guru namun siswa tetap mampu menyelesaikan soal. Siswa berfikir dengan mengikuti aturan-aturan atau langkahlangkah seperti yang dicontohkan guru maka mereka akan memperoleh jawaban yang benar. Guru tidak melakukan pengajaran bermakna dengan menggunakan metode pengajaran yang kurang variatif dan terkesan membosankan. Akibatnya, motivasi belajar siswa sulit ditumbuhkan dan pola belajarnya cenderung menghafal.

Berdasarkan hasil wawancara awal dengan siswa didapatkan informasi bahwa 9 dari 14 siswa menyatakan bahwa matematika adalah pelajaran yang sulit. Ada 10 dari 14 siswa juga mengaku bahwa mereka tidak menyukai pelajaran matematika. Adapula siswa yang malas mengerjakan soal matematika yang dianggap sulit. Bagi siswa yang tidak bersemangat biasanya guru memberi ancaman seperti, "bagi siswa yang belum selesai maka tidak boleh istirahat" kemudian dengan segera siswa mencoba mengerjakan. Ada pula siswa yang sering bertanya kepada guru kapan pelajaran berakhir akan tetapi ada beberapa siswa yang serius mengerjakan dan merasa senang dengan pelajaran matematika karena siswa tersebut lebih suka berhitung dari pada harus membaca. Berdasarkan pengakuan guru, ketika pelajaran berlangsung masih ada anak-anak yang gojeg, menggambar di buku tulisnya, sibuk sendiri dan tidak memperhatikan guru. Hal ini menunjukkan bahwa sikap siswa terhadap matematika masih belum positif.

Guru menganggap proses mengajar dan pengujian, serta evaluasi, sebagai kegiatan -kegiatan pendidikan yang terpisah (Shores \& Grace, 2006, p.10). Penilaian harusnya tidak semata-mata menilai siswa, tetapi harus dimanfaatkan juga untuk siswa, yakni untuk mengarahkan dan meningkatkan belajar siswa. Dalam paradigma lama, yang masih berlangsung sampai sekarang, evaluasi bersifat diskrit, dilakukan pada saat-saat tertentu saja yaitu pada (pada pertengahan caturwulan, akhir caturwulan atau akhir tahun), dan pada umumnya menggunakan asesmen berbentuk tes objektif, kadang-kadang disertai sedikit soal uraian. Evaluasi itu dalam kenyataannya dimaksudkan untuk mengetahui apa yang tidak diketahui siswa bukan untuk mengetahui apa yang diketahui dan dapat dilakukan siswa (Marpaung, 2005, p.29). Begitu juga di SD Muhammadi- yah Jogodayoh dimana siswa dinilai di setiap akhir pokok bahasan dengan ulangan harian, Ujian Tengah Semester, dan Ujian Akhir Semester. Guru belum melaksanakan penilaian yang menilai proses belajar seperti penilaian yang menggunakan asesmen portofolio. Penilaian yang dilakukan hanya berdasarkan hasil benar atau salah. Dari sistem penilaian yang seperti ini membuat siswa akan belajar apabila ada PR atau jika akan ujian.

Menurut Gravemeijer (1994, p.114) PMRI memiliki lima karakteristik pembelajaran matematika yaitu: 1) penggunaan konteks: proses pembelajaran diawali dengan keterlibatan siswa dalam pemecahan masalah kontekstual; 2) instrumen vertikal: konsep atau ide matematika direkonstruksikan oleh siswa melalui model-model instrumen vertikal, yang bergerak dari prosedur informal ke bentuk formal; 3) kontribusi siswa: siswa aktif mengkonstruksi bahan matematika berdasarkan fasilitas dengan lingkungan belajar yang disediakan guru; 4) kegiatan interaktif: kegiatan belajar bersifat interaktif, yang mungkin terjadi komunikasi dan negosiasi antarsiswa; dan 5) keterkaitan topik: pembelajaran suatu bahan matematika terkait dengan berbagai topik matematika secara terintegrasi.

Pendidikan Matematika Realistik Indonesia mengajak anak belajar matematika melalui lingkungannya, sehingga dengan pengalaman yang dimiliki anak ini pembelajaran matematika menjadi menyenangkan dan bermakna. Dengan pembelajaran yang menyenangkan maka sikap siswa terhadap matematika akan menjadi lebih positif dan motivasi belajar pun akan terbangun dengan sendirinya. Siswa harus dievaluasi dengan menggunakan metode, bahan-bahan dan pendekatan yang sama dengan yang mereka gunakan dalam pengajaran. Apabila proses pembelajaran menggunakan pendekatan pembelajaran yang kontekstual atau sering dikenal dengan PMRI maka asesmen yang digunakan pun harus sesuai dengan pendekatan tersebut. Asesmen yang cocok dengan PMRI adalah asesmen autentik seperti unjuk kerja atau portofolio. Namun sayangnya dalam pembelajaran matematika di SD Muhammadiyah Jogodayoh guru belum pernah menggunakan pendekatan PMRI maupun penilaian portofolio.

Definisi yang paling dasar dari portofolio adalah "folder of a child's work" yaitu kumpulan hasil karya anak (Herbert, 2001, p.44). Menurut Santrock (2008, p.588) "port- 
folio is a systematic and organized collection of a student's work that demonstrates the student's skill and accomplishments". Portofolio merupakan sekumpulan hasil karya siswa yang sistematis dan terorganisir, yang menunjukkan keahlian dan prestasi siswa. Portofolio tidak hanya kumpulan paper siswa atau kumpulan catatan yang disimpan di map saja. Portofolio merupakan karya atau hasil kerja yang dibuat dan ditata sedemikian rupa sehingga menunjukkan kemajuan siswa dan mengarah pada suatu tujuan. Berryman, Russel \& Richard (Santrock, 2008, p.591) menyatakan bahwa peranan asesmen portofolio dalam pembelajaran adalah portofolio memberi kesempatan untuk mendorong siswa membuat keputusan dan refleksi diri. Portofolio memotivasi siswa untuk berfikir kritis dan mendalam sehingga portofolio memberi mekanisme yang bagus untuk megevaluasi kemajuan dan peningkatan belajar siswa.

Penilaian dalam pembelajaran matematika tidak hanya menilai jawaban siswa benar atau salah namun harus menilai tujuan pembelajaran matematika secara spesifik seperti matematisasi, refleksi, dayacipta dan kreativitas siswa yang tentunya sulit dinilai dengan tes tradisional. Prinsip-prinsip penilaian pembelajaran matematika melalui pendekatan PMRI adalah (de Lange: 1987, pp.179181): 1) Penilaian harus meningkatkan pembelajaran.; 2) Metode penilaian yang digunakan harus mampu menggali apa yang diketahui siswa bukan apa yang tidak diketahui siswa.; 3) Metode penilaian harus mampu menilai kemampuan matematisasi, refleksi, daya-cipta, dan kreativitas siswa yang artinya penilaian berorentasi pada proses pembelajaran bukan hasil saja.; 4) Kemampuan siswa tidak bisa hanya digambarkan dengan penilaian objektif.

Berdasarkan karakteristiknya, penilaian portofolio sangat sesuai dengan prinsip penilaian dalam PMRI. Penilaian portofolio merupakan penilaian yang tidak hanya sekedar berorentasi pada hasil belajar siswa tetapi juga memantau proses pembelajaran. Adapun karakteristik penilaian portofolio diuraikan sebagai berikut: 1) Merupakan hasil karya siswa yang berisi kemauan siswa dan penyelesaian tugas-tugas secara terus-menerus dalam usaha pencapaian kompetensi pembelajaran.; 2) Portofolio dapat mengukur setiap prestasi siswa secara individual dan menyadari perbedaan di antara siswa.; 3) Merupakan suatu pendekatan kerja sama dalam pembelajaran.: 4)
Memiliki tujuan untuk menilai diri sendiri. 5) Portofolio dapat memperbaiki dan mengupayakan prestasi. 4) Adanya keterkaitan antara penilaian dan pembelajaran.

Schunk, Pintrich \& Meece (2008, p.5) menyatakan motivasi siswa menunjukkan ketertarikan siswa dalam aktivitas, mengerjakan tugas dengan rajin, merasa percaya diri, berkomitmen terhadap tugas dan kinerja yang baik. Ketika kinerja siswa kurang baik, guru mungkin akan mengatakan bahwa siswa tidak mempunyai motivasi untuk belajar tetapi mereka bisa mengerjakan lebih baik jika mereka mencoba lebih keras lagi. Motivasi dapat mempengaruhi apa, kapan, dan bagaimana kita belajar. Motivasi memiliki pengaruh yang besar terhadap kesuksesan pembelajaran. Apabila siswa memiliki motivasi yang baik maka siswa akan disiplin dan bersikap baik dalam belajar dan sebaliknya apabila siswa tidak memiliki motivasi yang baik dalam belajar maka guru harus berinovasi dalam mengajar.

Sikap merupakan proses evaluasi yang sifatnya internal atau subjektif yang berlangsung dalam diri seseorang dan tidak dapat diamati secara langsung. Sikap dapat diketahui melalui pengetahuan, keyakinan, perasaan, dan kecenderungan tingkah laku seseorang terhadap objek sikap. Kedalaman sikap seseorang terhadap objek dapat diukur melalui pengetahuannya, perasaannya, dan bagaimana ia memperlakukan objek tersebut. Sikap adalah konsep yang dibentuk oleh tiga komponen, yaitu kognitif, afektif, dan perilaku. Komponen kognitif berisi semua pemikiran serta ide-ide yang berkenaan dengan objek sikap. Isi pemikiran seseorang meliputi hal-hal yang diketahui sekitar objek sikap, dapat berupa tanggapan atau keyakinan, kesan, atribusi, dan penilaian tentang objek sikap (Istiqomah Wibowo, 2009, p.83).

Hasil penelitian tentang implentasi pembelajaran melalui pendekatan PMRI adalah pembelajaran matematika menjadi lebih efektif ditinjau dari hasil belajar, motivasi belajar, dan sikap siswa di SD (Dona Ningrum, 2010, p.132). Penelitian lain mengenai implementasi PMRI dalam pembelajaran menunjukkan hasil: (1) siswa suka dengan kurikulum PMRI dan percaya bahwa PMRI dapat meningkatkan kepercayaan diri dan kemampuan menyelesaikan masalah, (2) siswa dapat mengkonstruksi pengetahuannya sendiri setelah siswa melaksanakan aktifitas yang didesain dengan PMRI dan siswa menggunakan 
berbagai strategi untuk menyelesaikan masalah kontekstual, (3) kebanyakan siswa dapat menggunakan pengetahuan dan kemampuan yang dipelajari sebelumnya untuk pembelajaran berikutnya, (4) pembelajaran PMRI berpengaruh positif terhadap kepercayaan diri dan juga pemahaman, penyelesaian masalah, aktifitas, kreatifitas, dan motivasi, dan (5) nilai hasil belajar siswa saat pretest lebih baik dari pada nilai hasil posttest yaitu rata-rata 8 (Ahmad Fauzan, 2002, p.201). Kajian penelitian di atas, tentang implementasi PMRI dalam pembelajaran sedangkan penelitian ini mengenai implementasi PMRI dengan asesmen portofolio dalam pembelajaran matematika di SD.

Penelitian ini dibatasi pada implementasi PMRI dengan asesmen portofolio yang belum dilaksanakan di kelas dan pada sikap siswa terhadap matematika yang masih belum positif dimana siswa tidak menyukai matematika karena dianggap sulit serta motivasi belajar siswa yang masih rendah. Oleh karena itu, penelitian ini difokuskan pada upaya peningkatan sikap positif siswa terhadap mate-matika dan motivasi belajar siswa melalui PMRI dengan asesmen portofolio.

Rumusan masalah dalam penelitian ini adalah "Bagaimanakah implementasi PMRI dengan asesmen portofolio untuk meningkatkan sikap positif terhadap matematika dan motivasi belajar siswa?"

Tujuan utama rancangan penelitian ini adalah untuk meningkatkan sikap positif terhadap matematika dan motivasi belajar siswa melalui implementasi PMRI dengan asesmen portofolio dalam pembelajaran matematika di SD.

\section{Metode}

Jenis Penelitian

Metode penelitian yang dilakukan dalam penelitian ini adalah Penelitian Tindakan Kelas (PTK) yang juga dikenal dengan Classroom Action Research (CAR). Bentuk PTK ini merupakan penelitian kolaboratif dimana guru dilibatkan sebagai tim yang melaksanakan tindakan. Model PTK yang digunakan dalam penelitian ini adalah model Kemmis \& Tanggart. Masing-masing siklus terdiri dari tahapan perencanaan, tindakan, observasi, dan refleksi. Tujuan dari model Kemmis \& Tanggart adalah apabila pada awal pelaksanaan tidakan masih ditemukan adanya kekurangan maka dapat dilakukan perbaikan pada tindakan atau siklus selanjutnya sampai target yang diinginkan tercapai.

\section{Waktu dan Tempat Penelitian}

Penelitian ini dilaksanakan di SD Muhammadiyah Jogodayoh Sumbermulyo, Bambanglipuro Bantul, Yogyakarta. Penelitian dilaksanakan pada bulan September sampai dengan November 2012. Pemilihan lokasi penelitian ditentukan berdasarkan hasil dialog antara peneliti dan guru mengenai permasalahan yang terjadi di kelas. Kemudian peneliti dan guru melaksanakan observasi awal dan menyepakati untuk menindaklanjuti permasalah tersebut.

Subjek penelitian ini adalah siswa kelas IVC SD Muhammadiyah Jogodayoh yang berjumlah 14 siswa, terdiri dari 10 siswa putra dan 4 siswa putri. Dalam penelitian ini melibatkan guru kelas yaitu ibu Arum Sulistyani, S.Pd sebagai pelaksana tindakan dan peneliti yaitu Ibu Ida Nurmila Isandespha.

Guru dan peneliti mengidentifikasi permasalahan yang terjadi di kelas. Peneliti berperan sebagai perancang kegiatan pembelajaran. Peneliti merancang Rencana Pelaksanaan Pembelajaran (RPP), menyusun Lembar Kerja Siswa (LKS), menyiapkan media pembelajaran dan berperan menjadi observer. Guru kolaborator sebagai pelaksana rancangan pembelajaran di kelas sekaligus sebagai observer.

Desain Penelitian

\section{Perencanaan}

Perencanaan adalah mengembangkan rencana tindakan untuk meningkatkan motivasi belajar dan sikap positif siswa terhadap matematika. Pada tahap ini dilakukan langkahlangkah yang berupa: 1) Mengidentifikasi dan menetapkan permasalahan yang terjadi di kelas saat pembelajaran matematika, mengumpulkan data pendukung, merumuskan masalah dan menganalisisnya untuk menentukan hipotesis tindakan.; 2) Merancang RPP, menyusun LKS, dan menyiapkan media belajar.; 3) Menyiapkan instrumen pengamatan aktivitas siswa dan guru.

\section{Pelaksanaan Tindakan}

Persiapan yang dilakukan pada siklus I antara lain: mempersiapkan RPP sebagai pedoman dalam pelaksanaan kegiatan pembelajaran, lembar observasi aktivitas siswa dan tindakan guru sebagai pedoman bagi observer 
dalam melaksanakan pengamatan pelaksanaan tindakan melalui metode eksplorasi atau unjuk kerja dengan asesmen portofolio, LKS yang akan digunakan siswa sebagai petunjuk aktivitas belajar dan lembar kerja yang nantinya juga menjadi salah satu koleksi portofolio.

\section{Observasi}

Observasi dilaksanakan untuk memonitor pelaksanan tindakan secara berkelanjutan. Selama aktivitas pembelajaran berlangsung, peneliti dan peneliti sejawat melakukan pemantauan secara sistematis terhadap proses dan aktivitas belajar yang dilakukan guru dan siswa.

\section{Refleksi}

Refleksi dilakukan untuk melihat apakah proses tindakan pembelajaran yang dilakukan sudah memenuhi harapan atau tujuan yang telah ditentukan sebelumnya. Pada PTK refleksi dilakukan berulang-ulang dan dilakukan pada setiap siklus. Melalui refleksi inilah rancangan siklus yang berikutnya disusun sehingga lebih baik dari pada siklus yang sebelumnya.

Data, Instrumen, dan Teknik Pengumpulan Data

Data yang dikumpulkan dalam penelitian ini yaitu: data tentang sikap positif terhadap matematika, motivasi belajar siswa, dan aktivitas siswa dan tindakan guru selama pembelajaran. Instrumen penelitian ini divalidasi oleh ahli, yang dalam penelitian ini dilakukan oleh Dr. Heri Retnowati. Validasi oleh ahli atau praktisi ini bertujuan untuk memperoleh bukti validasi isi dan validasi konstruk instrumen. Setelah dikoreksi oleh validator, Instrumen tersebut direvisi berdasarkan masukan dari validator.

Instrumen yang digunakan dalam penelitian ini yaitu:

\section{Skala Sikap}

Skala sikap digunakan untuk mendapatkan informasi mengenai sikap siswa terhadap matematika. Skala sikap terdiri dari 26 item yang telah divalidasi oleh ahli atau tenaga profesional. Skala sikap berbentuk checklist menggunakan skala Linkert yang dimodifikasi dengan 4 (empat) alternatif jawaban yaitu: sangat setuju, setuju, tidak setuju, dan sangat tidak setuju. Skor masing-masing 4, 3, 2, dan 1 untuk pernyataan yang bersifat positif dan skor
$1,2,3$, dan 4 untuk pernyataan yang bersifat negatif.

\section{Pedoman Wawancara}

Instrumen yang digunakan untuk wawancara adalah pedoman wawancara yang sebelumnya telah disusun oleh peneliti dan telah divalidasi oleh ahli atau tenaga profesional. Jenis data yang dikumpulkan dengan pedoman wawancara merupakan data kualitatif. Pedoman wawancara disiapkan sebagai panduan peneliti sehingga informasi yang diperoleh bisa mendalam. Pedoman wawancara terdiri dari sepuluh item pertanyaan yang menggali motivasi intrinsik dan ekstrinsik siswa. Jenis data ini merupakan data kualitatif. Peneliti merekap hasil wawancara dengan menggunakan tape recorder.

\section{Lembar Observasi}

Kegiatan observasi dilakukan dengan pengamatan langsung oleh peneliti dan peneliti sejawat selama proses pembelajaran dilaksanakan. Observasi dilakukan kepada guru dan siswa melalui: lembar observasi terhadap aktivitas belajar siswa dan lembar observasi terhadap tindakan guru

Tabel 1. Teknik Pengumpulan Data

\begin{tabular}{clll}
\hline No & $\begin{array}{c}\text { Sumber } \\
\text { Data }\end{array}$ & Jenis Data & $\begin{array}{c}\text { Teknik } \\
\text { Pengumpulan } \\
\text { Data }\end{array}$ \\
\hline 1 & Siswa & $\begin{array}{l}\text { Sikap siswa } \\
\text { terhadap } \\
\text { matematika }\end{array}$ & $\begin{array}{l}\text { Skala Sikap } \\
\text { Siswa }\end{array}$ \\
2 & Siswa & $\begin{array}{l}\text { Motivasi belajar } \\
\text { siswa }\end{array}$ & Wawancara \\
3 & Siswa dan & $\begin{array}{l}\text { Aktivitas siswa } \\
\text { dan tindakan guru } \\
\text { selama } \\
\text { furu }\end{array}$ & Observasi \\
& & $\begin{array}{l} \\
\text { pembelajaran }\end{array}$ \\
\hline
\end{tabular}

Teknik Analisis Data

Penelitian tindakan ini mengunakan pendekatan kualitatif-kuantitatif. Sesuai dengan tujuan penelitian ini, teknik analisis data yang digunakan adalah sebagai berikut:

\section{Analisis Skala Sikap}

Untuk menentukan kriteria hasil pengukuran sikap siswa terhadap matematika digunakan klasifikasi rata-rata ideal (Mi) dan standar deviasi ideal (Si). Dalam penelitian ini sikap siswa terhadap matematika memiliki rentang antara 26 sampai dengan 104. Perhi- 
tungan rata-rata ideal dan standar deviasi ideal adalah sebagai berikut:

$$
\mathrm{Mi}=\frac{(26+104)}{2}=65 \text { dan } \mathrm{Si}=\frac{(104-26)}{6}=13
$$

Penafsiran rata-rata skor sikap positif disajikan pada Tabel 2.

\section{Analisis Motivasi Belajar Siswa}

Informasi mengenai motivasi siswa terhadap matematika didapat dari data hasil wawancara sehingga data yang diperoleh berupa data kualitatif yang akan dianalisis secara deskriptif kualitatif. Data hasil wawancara diklasifikasikan dan dikategorikan secara sistematis dan menurut karakteristiknya. Bentuk penyajian data hasil wawancara dalam bentuk bagan. Data hasil wawancara dikategorikan berdasarkan indikator motivasi belajar siswa. Jumlah jawaban siswa sesuai kategori dinyatakan dalam bentuk persen. Dalam penelitian ini ditetapkan pembelajaran dikatakan berhasil apabila $70 \%$ jawaban siswa atas pertanyaan wawancara menunjukkan adanya motivasi dalam belajar.

Tabel 2. Interval Kriteria Sikap Positif Siswa terhadap Matematika

\begin{tabular}{lll}
\hline \multicolumn{1}{c}{ Interval } & Skor $(\mathbf{X})$ & Kriteria \\
\hline$(\mathrm{Mi}+2 \mathrm{Si})<\mathrm{x} \leq(\mathrm{Mi}+3 \mathrm{Si})$ & $91<\mathrm{X} \leq 104$ & Sangat Positif \\
$(\mathrm{Mi}+1 \mathrm{Si})<\mathrm{x} \leq(\mathrm{Mi}+2 \mathrm{Si})$ & $78<\mathrm{X} \leq 91$ & Positif \\
$(\mathrm{Mi}-1 \mathrm{Si})<\mathrm{x} \leq(\mathrm{Mi}+1 \mathrm{Si})$ & $52<\mathrm{X} \leq 78$ & Cukup Positif \\
$(\mathrm{Mi}-2 \mathrm{Si})<\mathrm{x} \leq(\mathrm{Mi}-1 \mathrm{Si})$ & $38<\mathrm{X} \leq 52$ & Negatif \\
$(\mathrm{Mi}-3 \mathrm{Si})<\mathrm{x} \leq(\mathrm{Mi}-2 \mathrm{Si})$ & $26<\mathrm{X} \leq 38$ & Sangat \\
& & Negatif \\
\hline
\end{tabular}

Analisis Hasil Observasi

Rumus menghitung skor aktivitas siswa dan tindakan guru selama pembelajaran. $\mathrm{S}_{\mathrm{S}}=\frac{A}{B A}$

Keterangan:

S : Skor dari setiap observer

A : Jumlah skor aspek yang diperoleh

BA : Banyaknya Aspek yang diamati

Setelah mendapatkan skor yang diperoleh dari setiap observer kemudian menghitung skor total dari semua observer.

$\mathrm{S}_{\mathrm{t}}=\frac{S_{1}+S_{2}}{2}$

Keterangan:

St : Skor Total

S1 : Skor dari pengamat 1

S2 : Skor dari pengamat 2
Berikut ini penafsiran skor total aktivitas siswa (Tajudin Nur, 2008, p.4):

$3,50-4,00=$ Sangat Aktif

$2,50-3,49=$ Aktif

$2,00-2,49=$ Cukup Aktif

$1,55-1,99=$ Pasif

$0,00-1,54=$ Sangat Pasif

Adapun penafsiran skor total tindakan guru adalah:

$3,50-4,00=$ Sangat Baik

$2,50-3,49=$ Baik

$2,00-2,49=$ Cukup Baik

$1,55-1,99=$ Kurang Baik

$0,00-1,54=$ Sangat Kurang Baik

\section{Hasil Penelitian dan Pembahasan}

Deskripsi Data Hasil Penelitian Siklus I

\section{Rencana Tindakan}

Tindakan direncanakan untuk materi Kelipatan dan Faktor pada Kompetensi Dasar: 1) mendeskripsikan konsep faktor, 2) menentukan faktor dan kelipatan suatu bilangan. Pelaksanaan tindakan siklus I direncanakan 4 kali pertemuan yang akan membahas materi Faktor dan Kelipatan. Pada setiap pertemuan guru akan menyajikan masalah kontekstual sesuai karakteristik PMRI yang akan diselesaikan siswa secara berkelompok. Dalam pelaksanaan pembelajaran melalui pendekatan PMRI dengan asesmen portofolio guru menggunakan metode yang sesuai dengan materi pembelajaran. Pada pertemuan pertama guru akan menggunakan metode simulasi untuk membahas materi kelipatan bilangan. Pada pertemuan kedua guru akan menggunakan metode eksplorasi untuk membahas materi faktor bilangan. Pada pertemuan ketiga guru akan menggunakan metode kinerja siswa untuk mengembangkan keterampilan menentukan faktor bilangan. Pada pertemuan keempat siswa mengerjakan, menyusun, merevisi dan melakukan dialog portofolio dengan guru.

\section{Pelaksanaan Tindakan}

\section{- Pertemuan Pertama}

Berikut ini adalah langkah-langkah pembelajaran menentukan kelipatan melalui kegiatan simulasi menabung pada pertemuan pertama.

Tanya jawab sekitar menabung dan siswa memberikan contoh mengenai menabung

Guru bertanya kepada siswa tentang kegiatan menabung, "Siapa di rumah yang 
mempunyai celengan?" Beberapa siswa menjawab, "Saya Bu...!" sambil mengacungkan jari. Guru melanjutkan pertanyaan, "Berapa kirakira kalian menabung setiap harinya?" Ada siswa yang menjawab, "Limaratus Bu...!" Dari konteks nyata ini guru mengembangkan sebuah kegiatan menabung. Guru membagi siswa dalam kelompok dan meminta mereka untuk berdiskusi kira-kira berapa uang jajan yang bisa disisihkan oleh kelompok untuk di tabung setiap harinya.

Simulasi menabung

Siswa melakukan simulasi menabung dengan petunjuk pelaksanaan pada LKS 1 kegiatan menabung. Pada LKS siswa diminta menyelesaikan permasalahan sebagai berikut.

Setiap hari berapa uang jajan yang bisa

kalian sisihkan untuk ditabung?

Tuliskan hasil tabunganmu setiap harinya selama 20 hari!

Untuk menyeleaikan masalah ini siswa melakukan simulasi menabung menggunakan koin dan celengan secara berkelompok. Ada kelompok yang belum memahami maksud dari soal yang ada pada LKS.

Mendata kelipatan hasil tabungan

Siswa mendata kelipatan dari uang yang mereka tabung setiap harinya selama 20 hari. Kelompok 1 langsung menuliskan hasil simulasi mereka tanpa masalah. Kelompok 1 memasukkan uang $\mathrm{Rp} 500,00$ ke celengan kemudian uang yang ada di celengan dihitung jumlahnya, seperti itu seterusnya sampai 20 kali.

Perhitungan formal menentukan kelipatan

Pada level ini siswa dengan bimbingan guru sudah melakukan perhitungan formal tentang kelipatan bilangan. Dengan bantuan guru siswa sudah bisa mengembangkan prosedur perkalian untuk menentukan kelipatan dari suatu bilangan. Setelah ini siswa pun bisa mendeskripsikan pengertian dari kelipatan suatu bilangan.

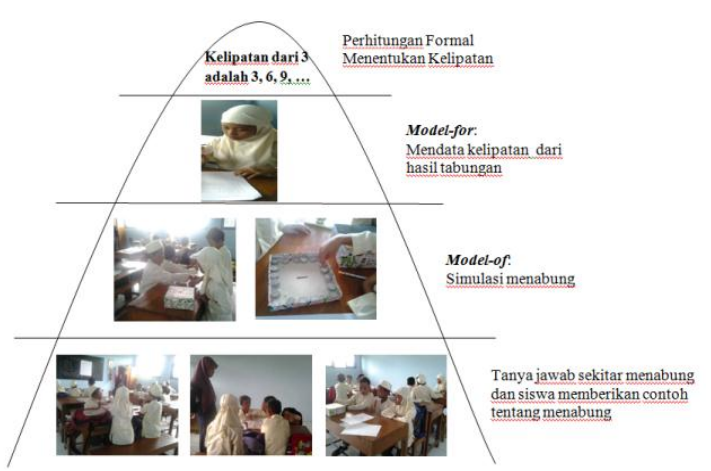

Gambar 1. Iceberg Proses Pembelajaran Menentukan Kelipatan Bilangan

\section{- Pertemuan Kedua}

Berikut ini adalah langkah-langkah pembelajaran menentukan faktor bilangan melalui implementasi PMRI menggunakan metode eksplorasi berbagi kue pada pertemuan kedua.

Siswa melakukan eksplorasi.

Siswa melakukan eksplorasi untuk menyelesaikan masalah konteks yang ada pada LKS 3 kegiatan berbagi kue. Pada LKS 3 siswa diminta menyelesaikan permasalahan sebagai berikut. Ibu mempunyai 15 Oreo. Ibu ingin menempatkan Oreo tersebut ke dalam piring-piring dengan bagian yang sama. Berapa sajakah kemungkinan piring yang bisa digunakan ibu? Untuk menyeleaikan masalah ini siswa melakukan eksplorasi dengan koin dan celengan secara berkelompok.

Menggambar hasil eksplorasi

Pada level ini siswa menggambarkan hasil eksplorasi mereka. Ada kelompok yang tidak mengalami kesulitan untuk menggambarkan hasil eksplorasi mereka namun ada juga kelompok yang merasa bingung untuk menggambarkannya.

\section{Mendata faktor bilangan}

Siswa mendata faktor dari 15 . Kelompok 3 langsung menuliskan bahwa piring yang mungkin digunakan oleh ibu sebanyak faktor dari 15.

Perhitungan formal menentukan faktor bilangan.

Pada level ini siswa dengan bimbingan guru sudah melakukan perhitungan formal tentang faktor bilangan. Dengan bantuan guru siswa sudah bisa mengembangkan prosedur pembagian untuk menentukan faktor dari suatu 
bilangan. Setelah ini siswa pun bisa mendeskripsikan pengertian dari faktor suatu bilangan.

Penilaian yang digunakan dalam pembelajaran ini adalah asesmen autentik portofolio yang bertujuan menilai proses dan hasil belajar siswa.

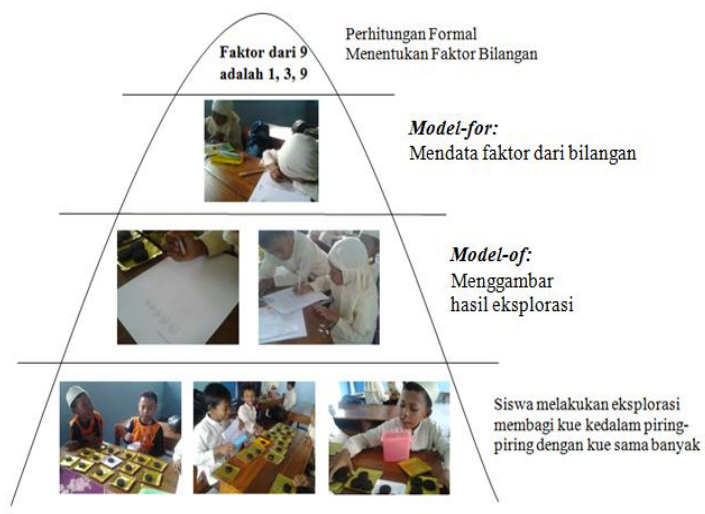

Gambar 2. Iceberg Proses Pembelajaran Menentukan Faktor Bilangan

\section{- Pertemuan Ketiga}

Metode yang digunakan di pertemuan ketiga adalah kinerja siswa untuk membuat hiasan candela. Tujuan pembelajarannya adalah melatih keterampilan siswa dalam menentukan faktor bilangan. Pada inti pembelajaran guru membagikan LKS 6 sebagai pentunjuk untuk membuat hiasan jendela. Guru juga membagikan satu paket peralatan seperti gunting, selotip, pita, kertas lipat, lem, penggaris, dan spidol untuk setiap siswa. Guru membimbing siswa untuk menentukan faktor dari bilangan yang ada pada LKS 6. Setiap siswa memperoleh bilangan yang berbeda, ada yang mendapat bilangan $8,9,10,12$, dan 15 . Setelah selesai menentukan faktornya siswa diminta menyusunya menjadi hiasan jendela.

\section{- Pertemuan Keempat}

Pada perencanaan jadwal penilaian portofolio pertemuan keempat ini bertujuan untuk menyusun, menambah, dan merevisi portofolio siswa. Selain itu juga pada pertemuan ini guru akan melaksanakan dialog portofolio.

Siswa membuat folder portofolio dan menghiasnya menggunakan alat-alat yang telah dibagikan oleh guru. Siswa membuat kelengkapan isi portofolionya masing-masing. Dengan bimbingan guru siswa menempelkan foto hasil karya "hiasan jendela" mereka pada kertas manila dan menuliskan langkah-langkah pembuatan hiasan jendela tersebut. Siswa memilih foto diri mereka saat beraktivitas dalam pembelajaran sebelumnya dan menuliskan cerita tentang foto diri tersebut. Kemudian siswa membuat daftar isi portofolio mereka masing masing. Siswa merapikan dan menyusun folder portofolionya dengan mengurutkan koleksi portofolio mereka sesuai dengan daftar isinya. Siswa merapikan alat-alat yang telah mereka gunakan untuk menghias portofolio mereka.

Di akhir pembelajaran guru melaksanakan dialog portofolio secara klasikal. Guru menanyakan isi dari portofolio siswa dan meminta siswa untuk menjelaskannya. Kemudian guru membuat catatan kecil mengenai kompetensi yang berkembang pada siswa. Di bagian penutup guru melakukan refleksi dengan menanyakan kebermanfaatan koleksi portofolio. Guru memancing siswa dengan pertanyaan dan contoh-contoh untuk menyebutkan keterkaitan antara materi yang telah dipelajari dengan mata pelajaran lain dan kehidupan sehari-hari. Guru menyampaikan kegiatan pembelajaran berikutnya yaitu Kelipatan Persekutuan Terkecil (KPK). Guru membimbing siswa untuk mengisi lembar penilaian diri dan langsung dimasukkan ke dalam koleksi portofolio.

\section{Observasi}

Hasil observasi aktivitas siswa saat pembelajaran melalui pendekatan PMRI dengan asesmen portofolio, pada pertemuan pertama siswa masih belum terbiasa belajar dengan pendekatan PMRI dengan metode eksplorasi dan diskusi sehingga siswa masih merasa bingung dan kesulitan. Penggunaan konteks dan instrumen vertikal siswa sudah cukup baik. Siswa masih belum menuliskan semua aktivitas-aktivitas yang mereka lakukan dalam pembelajaran, hanya kelompok tiga yang menuliskan hasil coret-coretan mereka di lembar jawab. Dalam pemanfatan hasil kontruksi siswa, interaktivitas, dan keterkaitan masih kurang. Ide siswa untuk menyelesaikan masalah sudah mulai nampak namun mereka masih terjebak pada cara-cara teknis matematis. Siswa juga masih belum bisa melihat keterkaitan materi yang mereka pelajari dengan pelajaran lain tetapi sudah bisa melihat keterkaitan matematika dengan kehidupan sehari-hari.

Dari hasil observasi tentang kegiatan guru yaitu, guru baru pertamakalinya mengalikasikan pendekatan PMRI dengan penilaian portofolio sehingga guru masih belum maksimal dalam mengaplikasikan pembelajaran 
menggunakan pendekatan PMRI dengan asesmen portofolio. Guru sudah menggunakan konteks yang menarik dan sesuai dengan pengalaman siswa namun belum memotivasi siswa untuk belajar matematika. Guru masih banyak mengarahkan siswa. Guru juga masih langsung memberikan jawaban apabila siswa bertanya yang seharusnya guru meminta pendapat dari siswa lain.

Dari hasil observasi tentang tindakan guru dalam menyusun portofolio selama satu siklus diperoleh rata-rata 2,56 yang masuk pada kriteria baik. Rata-rata aktivitas siswa dalam menyusun portofolio termasuk kriteria cukup aktif dan rata-rata tindakan guru dalam menyusun portofolio termasuk pada kriteria baik. Dari hasil wawancara juga dapat dilihat bahwa sebagian siswa masih belum mengerti apa manfaat portofolio. Siswa juga belum maksimal dalam merefleksikan hasil belajar yang telah diperolehnya.

Refleksi

Data yang diperoleh dari hasil observasi kemudian dianalisa dan dilakukan refleksi. Refleksi dilakukan antara peneliti dan guru yang bertujuan mengevaluasi tindakan yang telah dilakukan. Hasil refleksi peneliti dan guru pada siklus pertama adalah sebagai berikut: a) ada pertemuan awal siklus I siswa masih kesulitan dalam memahami soal. Bahasa yang digunakan dalam soal tidak mudah dipahami oleh siswa. Soal latihan yang diberikan guru juga terlalu banyak sehingga diakhir pembelajaran siswa sudah kehabisan energi dan kelihatan kelelahan.; b) implementasi pembelajaran PMRI melalui metode simulasi, eksplorasi, dan kinerja siswa pada siklus I ini merupakan hal yang baru di kelas sehingga siswa belum terbiasa aktif dalam pembelajaran.; c) Siswa juga belum terbiasa mendengarkan dan menghargai pendapat orang lain.; d) Pada siklus I ini siswa juga masih belum bisa mengaitkan materi matematika yang dipelajari dengan mata pelajaran lain atau masalah sehari-hari.; e) Guru masih belum membimbing siswa untuk mengkontruksi pengetahuannya sendiri. Guru masih banyak mengintervensi siswa dalam pembelajaran.; f) Penyusunan portofolio juga masih belum maksimal. Hal ini bisa dilihat dari hasil observasi pada aktivitas siswa dan tindakan guru dalam menyusun portofolio.; g) Orang tua belum maksimal dalam memberikan feedback pada setiap tugas portofolio siswa. Ada beberapa orang tua siswa yang hanya menandatangani tugas portofolio anaknya sehingga belum ada komunikasi antara orang tua dan guru melalui koleksi portofolio yang telah disusun siswa.

Untuk mengatasi kekurangan pada siklus I, guru akan memperbaiki proses pembelajarannya pada siklus II. Di siklus II guru akan lebih intensif dalam membimbing siswa untuk mengkontruksi sendiri pengetahuannya. Berdasarkan dan guru akan lebih jelas dalam menyampaikan tujuan dan kriteria penilaian portofolio. Guru juga akan berusaha memaksimalkan peranan orang tua dalam memberikan feedback tertulis pada setiap tugas portofolio siswa. Guru akan mengambil materi KPK dan FPB pada siklus II.

\section{Deskripsi Data Hasil Penelitian Siklus II}

\section{Rencana Tindakan}

Pada siklus II tindakan yang dilaksanakan pada prinsipnya sama dengan siklus I. Pada siklus II di pertemuan kelima akan membahas materi menentukan KPK dan masalah sehari-hari yang berkaitan dengan KPK. Pembelajaran matematika melalui pendekatan PMRI pada materi KPK akan disajikan dengan menggunakan metode permainan. Berdasarkan hasil diskusi dengan guru materi KPK akan menjadi lebih mudah dipahami siswa apabila diterapkan dengan metode permainan. Melalui permainan diharapkan siswa akan menjadi lebih mudah memahami soal yang akan diberikan. Bahasa yang digunakan dalam soal tidak mudah dipahami oleh siswa.

Materi FPB dan masalah sehari-hari yang berkaitan dengan FPB akan dibahas pada pertemuan keenam. Pada pertemuan ini pembelajaran dengan pendekatan PMRI akan disajikan dengan metode eksplorasi. Melalui metode eksplorasi siswa diharapkan dapat mengkonstruksi pengetahuannya sendiri. Guru harus memfasilitasi siswa untuk menemukan sendiri konsep matematika melalui metode eksplorasi ini.

Tindakan selanjutnya pada siklus II ini yaitu menyusun portofolio pelajaran matematika dimana siswa mengerjakan, menyusun, dan merevisi portofolionya dan guru lebih jelas dalam menyampaikan tujuan dan kriteria penilaian portofolio. Kriteria penilaian portofolio disampaikan dengan bahasa yang mudah dipahami oleh siswa. Dalam siklus II ini guru juga masih berusaha untuk melibatkan semua 
orang tua untuk memberikan feedback secara tertulis terhadap hasil belajar siswa.

\section{Pelaksanaan Tindakan}

\section{- Pertemuan Kelima}

Pada pertemuan kelima, implementasi PMRI menggunakan metode permainan. Berikut ini adalah langkah-langkah pembelajaran KPK melalui permainan dengan tema Tepuk Tangan Gembira:

Melakukan permainan "Tepuk tangan gembira"

Guru membagi siswa menjadi 2 kelompok besar. Kelompok 1 terdiri dari 7 siswa dan kelompok 2 juga tujuh siswa. Aturan permainannya, guru meminta siswa untuk berdiri berhadapan. Guru berhitung secara lambat 1 sampai 20, kelompok 1 bertepuk tangan pada kelipatan 2, kelompok 2 bertepuk tangan pada kelipatan 3, bagi kelompok yang melakukan kesalahan akan mendapatkan kartu "smile sedih" dan ditempelkan pada ketua kelompok, dan bagi kelompok yang memiliki sedikit kartu "smile sedih" adalah pemenangnya.

Kemudian guru mengarahkan siswa untuk menemukan kelipatan persekutuan dari permainan tersebut dengan bertanya, "Dari permainan tadi pernahkah kelompok 1 dan 2 bertepuk tangan bersama?" Siswa menjawab serentak, "Pernah". Guru bertanya lagi, "Pada hitungan ke berapa saja?" Siswa menjawab serentak, "Enam, dua belas, delapan belas". Guru mengapresiasi, "Bagus....!"

Memberikan masalah kontekstual membuat jadwal les siswa

Guru menyuguhkan permasalahan pada Lembar Kerja 1 mengenai membuat jadwal les. Pada LKS siswa diminta menyelesaikan soal sebagai berikut. Ibu guru akan membuat jadwal les untuk bulan Oktober 2012 bagi siswa kelas 4 dan kelas 5. Siswa kelas 4 les setiap 2 hari sekali dan siswa kelas 5 les setiap 3 hari sekali. Gunakan tanggalan berikut untuk membantu Bu guru membuat jadwal les! Tandai jadwal les kelas 4 dengan lingkaran dan jadwal les kelas 5 dengan persegi!

1) Tanggal berapa saja kelas 4 harus les?

2) Tanggal berapa saja kelas 5 harus les?

3) Apakah kelas 4 dan kelas 5 pernah les bersamaan?

4) Tanggal berapa saja kelas 4 dan kelas 5 les bersamaan?

Mendata kelipatan bilangan
Dari konteks permasalahan tersebut siswa mendata kelipatan dari 2 dan 3. Pada level ini siswa tidak mengalami kesulitan.

\section{Menentukan bentuk formal KPK}

Level yang terakhir dari pengembangan model matematika adalah level formal. Pada level ini siswa dengan bantuan guru mulai mengembangkan konsep matematis mengenai Kelipatan Persekutuan Terkecil. Pada level sebelumnya siswa sudah bisa mendata kelipatan dari masing-masing bilangan tersebut, hampir semua siswa bisa melihat bahwa ada kelipatan yang sama. Guru menegaskan kepada siswa bahwa kelipatan yang sama inilah yang disebut sebagai kelipatan persekutuan. Dari beberapa kelipatan persekutuan yang sudah di data, siswa bisa KPK.

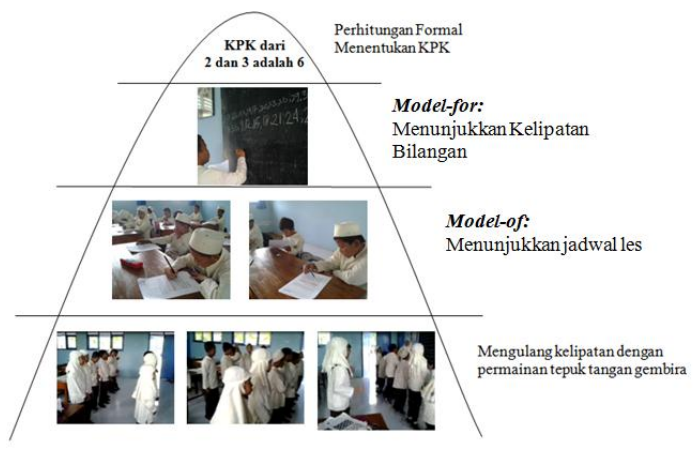

Gambar 3. Iceberg Proses Belajar KPK

\section{- Pertemuan Keenam}

Implementasi PMRI pada pertemuan keenam menggunakan metode eksplorasi. Berikut ini adalah langkah-langkah pembelajaran FPB melalui kegiatan eksplorasi dengan tema Ulang Tahun:

Memberikan masalah konteks berupa merayakan ulang tahun.

Guru menyuguhkan permasalahan pada LKS 3 tentang kegiatan ulang tahun. Siswa menyelesaikan masalah koneks secara berkelompok. Pada LKS siswa diminta menyelesaikan soal sebagai berikut. Pada tanggal 30 Oktober Ida berulang tahun. Ida ingin membagikan bingkisan permen dan roti rose kepada beberapa temannya. Ida memiliki 8 permen dan 20 roti rose. Setiap permen dan roti rose dibagikan dengan jumlah sama banyak. Sekarang, bantulah Ida menyiapkan bingkisan tersebut! Berapa jumlah bingkisan yang mungkin dibuat?; Paling banyak berapa bingkisan yang bisa kamu buat?; Jika bingkisan sudah siap, hiaslah setiap bingkisan dengan pita dan kartu 
ucapan!; Mencari faktor melalui kegiatan membuat bingkisan ulang tahun.

Dari masalah konteks yang diberikan oleh guru, siswa melakukan eksplorasi untuk membuat bingkisan ulang tahun yang mungkin mereka buat. Siswa dalam bereksplorasi menggunakan pengetahuan yang sudah mereka miliki mengenai faktor dari 8 dan 20. Siswa mencoba-coba membuat bingkisan dengan faktor dari 8 dan 20. Dari sini siswa berfikir bahwa bingkisan yang bisa mereka buat sebanyak bilangan yang bisa membagi habis 8 permen dan 20 roti rose.

\section{Menentukan bentuk formal FPB}

Berdasarkan pengetahuan siswa sebelumnya dalam mencari KPK, siswa dengan mudah menemukan bahwa pada bilangan 8 dan 20 terdapat faktor yang sama yang disebut faktor persekutuan. Siswa juga menemukan dari faktor yang sama tersebut, faktor yang terbesar disebut Faktor Persekutuan Terbesar (FPB).

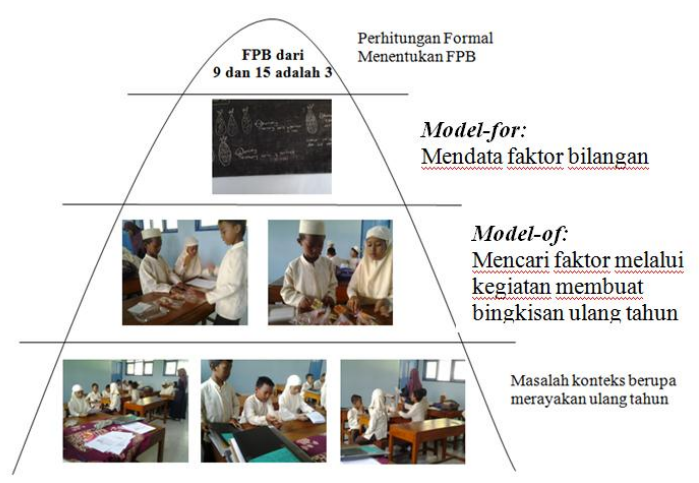

Gambar 4. Iceberg Proses Belajar FPB

Mendata faktor bilangan.

Siswa bereksplorasi dan menemukan solusi dari masalah yang mereka selesaikan kemudan siswa menggambarkan hasil penemuan mereka. Setelah mereka menggambarkan penemuan mereka kemudian siswa menuliskan symbol matematika dari gambar yang mereka peroleh. Pada level ini siswa mendata faktor bilangan dari 8 dan 20. Siswa tidak mengalami kesulitan dalam menentukan faktor bilangan.

\section{Observasi}

Rata-rata aktivitas siswa 3,78 dan masuk pada kriteria sangat aktif. Siswa semakin berani mengungkapkan ide atau mengemukakan masalah yang dihadapi dalam proses pembelajaran. Siswa berani mengutarakan ide atau pendapatnya dengan terbuka. Semua siswa aktif dalam belajar. Siswa sudah tidak malu- malu lagi untuk menuliskan hasil pekerjaannya di depan kelas bahkan saling berebut.

Hasil observasi tentang tindakan guru dalam menerapkan pendekatan PMRI. Dari hasil observasi tentang kegiatan guru diperoleh rata-rata 3,83 yang masuk pada kriteria sangat baik. Guru sudah sangat baik menunjukkan keterkaitan materi yang dipelajari dengan mata pelajaran lain. Guru juga sudah sangat baik dalam membimbing siswa untuk mengkonstruksi pengetahuannya sendiri melalui konteks yang bervariasi dan bermakna.

Dari hasil observasi tentang aktivitas siswa dalam menyusun portofolio selama satu siklus diperoleh rata-rata 3,00 yang masuk pada kriteria aktif. Siswa aktif dalam menyusun portofolio, bersungguh-sungguh, dan merawat portofolionya dengan baik. Pada pertemuan yang ketujuh ini siswa sudah paham tentang tujuan penyusunan portofolionya. Semua siswa menuliskan refleksi terhadap kemajuan belajarnya dalam lembar evaluasi diri namun hanya ada sedikit siswa yang benarbenar bisa menuliskan perkembangan dirinya. Siswa masih belum bisa menuliskan hasil belajar yang penting bagi dirinya dalam lembar evaluasi diri. Hanya beberapa siswa yang selalu memperbaiki isi portofolionya.

Dari hasil observasi tentang tindakan guru dalam menyusun portofolio selama satu siklus diperoleh rata-rata 3,11 yang masuk pada kriteria baik. Pada siklus II ini guru selalu menyampaikan kriteria penilaian portofoli. Dalam menyampaikan kriteria penilaian portofolio guru tidak menyampaikannya dengan rinci namun hanya disampaikan secara garis besar dan dengan menggunakan bahasa yang bisa dipahami oleh siswa. Komunikasi antara guru, siswa dan orang tua melalui portofolio terjalin cukup efektif.

\section{Refleksi}

Setelah dilaksanakan tindakan pada siklus II, sikap siswa terhadap matematika telah mengalami peningkatan. Skor sikap siswa terhadap matematika pada siklus II adalah 86,79 dengan kriteria positif. Pada siklus I rata-rata skor sikap siswa adalah 81,50 dengan kriteria positif dan $64,29 \%$ memiliki sikap positif terhadap matematika. Pada siklus II ratarata sikap siswa terhadap matematika meningkat menjadi 86,76 dengan kriteria positif dan $85,71 \%$ siswa sudah memiliki sikap positif dan sangat positif terhadap matematika. 
Meningkatnya sikap siswa terhadap matematika juga membawa peningkatan pada motivasi belajar siswa. Motivasi belajar siswa juga mengalami peningkatan. Hal ini berdasarkan hasil wawancara, masih ada 50\% siswa yang tidak memberikan jawaban tentang "Apa yang akan dilakukan jika mendapatkan nilai jelek?" Sedangkan, pada siklus II 78,57\% siswa menjawab akan belajar lagi apabila mendapatkan nilai jelek. Pada siklus I motivasi siswa masih sangat dipengaruhi oleh lingkungan belajar. Dari data hasil wawancara pada siklus I dapat dilihat ada 64,29\% siswa yang tetap belajar walaupun suasana kelas tidak mendukung. Pada siklus II sudah meningkat menjadi $78,54 \%$ siswa tetap belajar meskipun kondisi kelas tidak mendukung.

Selain peningkatan sikap siswa terhadap matematika dan motivasi belajar, hasil belajar siswa pun mengalami peningkatan. Ratarata hasil belajar siswa pada siklus I adalah 79,25 dan rata-rata hasil belajar siswa pada siklus II adalah 82,52. Penilaian yang dilakukan dengan menggunakan penilaian portofolio.

Berdasarkan data hasil skala sikap siswa dan hasil wawancara siswa mengenai motivasi belajar pada siklus II ini sikap siswa terhadap matematika dan motivasi belar siswa telah mengalami peningkatan sesuai dengan target yang telah ditetapkan. Oleh karena itu, penelitian diakhiri pada siklus II.

Analisis Hasil Penelitian

\section{Analisis Sikap Positif terhadap Matematika}

Tabel 3 Peningkatan Kriteria Sikap Positif

Siswa terhadap Matematika tiap Siklus (dalam \%)

\begin{tabular}{llccc}
\hline No & \multirow{2}{*}{ Kriteria } & $\begin{array}{c}\text { Pra } \\
\text { Siklus }\end{array}$ & $\begin{array}{c}\text { Siklus } \\
\text { I }\end{array}$ & $\begin{array}{c}\text { Siklus } \\
\text { II }\end{array}$ \\
\hline 1 & Sangat Positif & 0 & 0 & 57,14 \\
2 & Positif & 21,43 & 64,29 & 28,57 \\
3 & Cukup Positif & 78,57 & 35,71 & 14,29 \\
4 & Negatif & 0 & 0 & 0 \\
5 & Sangat Negatif & 0 & 0 & 0 \\
\hline
\end{tabular}

Tabel 3 menyajikan data mengenai peningkatan sikap positif siswa terhadap matematika dari sebelum tindakan sampai setelah dilaksanakan tindakan dalam persen.

\section{Analisis Motivasi Belajar Siswa}

Berikut ini adalah peningkatan sikap positif siswa terhadap matematika dari sebelum tindakan sampai setelah dilaksanakan tindakan dalam persen.
Tabel 4 Peningkatan Motivasi Belajar Siswa tiap Siklus (dalam \%)

\begin{tabular}{lccc}
\hline & \multicolumn{3}{c}{ Persentase (\%) } \\
\cline { 2 - 4 } Kategori & $\begin{array}{c}\text { Pra } \\
\text { Siklus }\end{array}$ & $\begin{array}{c}\text { Siklus } \\
\text { I }\end{array}$ & $\begin{array}{c}\text { Siklus } \\
\text { II }\end{array}$ \\
\hline \multicolumn{3}{c}{ Motivasi Intrinsik } \\
$\begin{array}{l}\text { Siswa belajar lebih giat } \\
\text { apabila memperoleh nilai } \\
\text { jelek }\end{array}$ & 7,14 & 50,00 & 92,86 \\
$\begin{array}{l}\text { Siswa meneliti kembali } \\
\text { hasil pekerjaanya }\end{array}$ & 42,86 & 64,29 & 71,42 \\
$\begin{array}{l}\text { Siswa tahu kegunaan } \\
\text { matematika dalam } \\
\text { kehidupan sehari-hari }\end{array}$ & 35,71 & 50,00 & 92,86 \\
$\quad$ Motivasi Ekstrinsik & & \\
$\begin{array}{l}\text { Siswa tetap belajar } \\
\text { walaupun situasi kelas }\end{array}$ & 28,57 & 64,29 & 78,57 \\
tidak mendukung & & & \\
\hline
\end{tabular}

\section{Pembahasan}

Setelah dilakukan tindakan dengan menggunakan pendekatan PMRI melalui metode simulasi, eksplorasi, dan kinerja siswa dengan asesmen portofolio yang juga melibatkan orang tua siswa untuk memberikan feedback secara tertulis pada setiap tugas portofolio siswa terjadi peningkatan rata-rata sikap siswa terhadap matematika menjadi 81,50 dengan kriteria positif dan baru $64,29 \%$ siswa memiliki sikap positif. Karena belum memenuhi target yang diinginkan maka dilaksanakan tindakan berikutnya pada siklus II. Tindakan yang dilakukan pada siklus II yaitu implementasi PMRI melalui metode permainan dan eksplorasi dengan asesmen portofolio yang melibatkan orang tua siswa. Setelah dilaksanakan tindakan pada siklus II rata-rata sikap siswa terhadap matematika meningkat menjadi 86,79 dengan kriteria positif dan $85,71 \%$ siswa memiliki sikap positif dan sangat positif.

Hasil penelitian ini menunjukkan bahwa implementasi PMRI dapat meningkatkan sikap positif terhadap matematika. Hal ini sesuai dengan teori yang disampaikan oleh Leiss., et al. (dalam Ariyadi, 2012, p.47) bahwa pemodelan yang dilaksanakan dalam PMRI dapat mengembangkan sikap positif siswa terhadap matematika. Pemodelan dalam matematika berfungsi sebagai jembatan dari pengetahuan matematika tingkat konkret menuju pengetahuan matematika tingkat formal. Dalam PMRI ada dua macam model yaitu model-of dan model-for. Model-of adalah model untuk menggambarkan situasi konteks dalam matematika dan model-for adalah model yang di- 
kembangkan untuk mencari solusi secara matematis.

Meningkatnya motivasi belajar siswa bisa dilihat dari data hasil wawancara. Sebelum dilaksanakan tindakan hanya 7,14\% siswa yang memiliki motivasi untuk belajar lebih giat apabila mendapatkan nilai jelek dalam matematika dan pada siklus I meningkat menjadi 50\% siswa. Pada siklus II terjadi peningkatan yang cukup signifikan yaitu ada $92.86 \%$ siswa yang termotivasi untuk belajar lebih giat apabila mendapatkan nilai matematika yang jelek. Artinya hampir seluruh siswa memiliki motivasi yang tinggi dalam belajar. Dari data ini bisa disimpulkan bahwa motivasi belajar siswa meningkat setelah dilaksanakan tindakan pembelajaran dengan pendekatan PMRI.

Sikap siswa terhadap matematika dilihat dari dimensi penilaian juga terjadi peningkatan walaupun peningkatannya tidak signifikan. Berdasarkan data awal rata-rata skor skala sikap siswa pada dimensi penilaian matematika adalah 15,36 dengan kriteria sikap positif. Setelah dilaksanakan tindakan dengan penilaian portofolio rata-rata skor skala sikap siswa pada dimensi penilaian matematika meningkat menjadi 15,64 dengan kriteria positif dan pada siklus II skor skala sikapnya meningkat menjadi 15,71 dengan kriteria tetap positif. Selain dilihat dari skor skala sikap siswa terhadap matematika pada dimensi penilaian matematika, sikap siswa terhadap penilaian dengan portofolio dapat dilihat dari data hasil wawancara siswa. Dari wawancara dengan pertanyaan "apakah kalian suka mengumpulkan hasil belajar matematika kalian dalam portofolio?" dari 14 siswa awalnya $85,71 \%$ menjawab suka dan meningkat menjadi $100 \%$ pada siklus I dan II. Hal ini sesuai dengan pendapat Zubizarreta (2004, p.125) yeng menyatakan pembelajaran dengan penilaian portofolio diharapkan dapat meningkatkan semua kemampuan dalam diri siswa agar menjadi lebih baik. Selain itu, dengan menyusun portofolio sikap belajar siswa menjadi lebih baik dan kemampuan intelektualnya juga berkembang pada level yang lebih tinggi.

Dari hasil wawancara diperoleh data awal $85,71 \%$ siswa suka mengumpulkan hasil belajar matematika dan hanya $50 \%$ siswa yang mengaku bisa memanfaatkan koleksi hasil matematikanya itu untuk belajar. Setelah dilaksanakan tindakan pada siklus I siswa yang suka mengumpulkan hasil belajarnya meningkat menjadi 100\% namun baru ada 50\% siswa yang memanfaatkan portofolionya untuk bel- ajar lagi. Setelah siklus II 100\% siswa sudah memanfaatkan hasil portofolionya untuk belajar lagi. Dari sini bisa disimpulkan bahwa motivasi belajar siswa meningkat setelah dilaksanakan tindakan pembelajaran PMRI dengan asesmen portofolio. Penilaian portofolio sebagai salah satu jenis penilaian berbasis kelas dapat digunakan sebagai upaya untuk mengenali kekuatan dan kelemahan peserta didik sehingga akan memotivasi siswa dalam belajar (Sumarna \& Muhammad, 2004, p.8).

\section{Simpulan dan Saran}

Simpulan

Berdasarkan analisis data dan pembahasan hasil penelitian dapat diambil kesimpulan sebagai berikut:

Tindakan pembelajaran matematika dengan pendekatan PMRI melalui metode permainan dan eksplorasi dengan asesmen portofolio yang melibatkan orang tua siswa untuk memberikan feedback kepada setiap tugas portofolio siswa dapat meningkatkan sikap positif siswa terhadap matematika.

Tindakan pembelajaran matematika dengan pendekatan PMRI melalui melalui metode permainan dan eksplorasi dengan asesmen portofolio yang melibatkan orang tua siswa untuk memberikan feedback kepada setiap tugas portofolio siswa dapat meningkatkan motivasi belajar Siswa

\section{Keterbatasan Penelitian}

Adapun keterbatasan dari penelitian ini adalah Keterbatasan siswa dalam mendeskripsikan pengalaman dan menyampaikan maksudnya mengakibatkan kurang mendalamnya hasil wawancara yang dilakukan oleh peneliti terhadap siswa untuk mengetahui motivasi belajar siswa.

Pada implementasi PMRI metode yang digunakan dalam setiap siklus berbeda. Pada siklus I metode yang digunakan adalah metode simulasi, eksplorasi, dan kinerja siswa dan pada siklus II metode yang digunakan adalah metode eksplorasi dan permainan. Hal ini menghasilkan kesimpulan yang berbeda dari hipotesis penelitian.

Karena keterbatasan waktu sehingga komunikasi yang dijalin antara guru dengan orang tua pada asesmen portofolio hanya dilakukan secara tertulis tidak bisa bertatapmuka langsung. 
Saran

Berdasarkan hasil dan temuan yang diperoleh serta dengan memperhatikan keterbatasan penelitian, saran yang disampaikan adalah sebagai berikut: 1) Perlu adanya penelitian lanjutan mengenai PMRI dengan asesmen yang digunakan selain asesmen portofolio, 2) Guru dalam pembelajaran menggunakan pendekatan PMRI hendaknya membimbing siswa dengan langkah-langkah yang jelas sehingga siswa bisa menemukan sendiri pengetahuan formal dari materi matematika yang sedang dibahas.

\section{Daftar Pustaka}

de Lange, J. (1987). Mathematics insight and meaning. Utrech: OW \& OC.

Djohar. (2009). Pengembangan pendidikan nasional menyongsong masa depan. Yogyakarta: Grafika Indah.

Fauzan, Ahmad. (2002). Applying Realistic Mathematics Education (RME) in teaching geometry in indonesian primary schools. Diambil pada tanggal 03 Januari 2013, dari http://doc.utwente.n1/58707/1/thesis_Fauzan.pdf

Gravemeijer, K. (1994). Developing realistic mathematics education. Utrecht: Freudenthal Institute.

Marpaung, Y. (2005). Reformasi pembelajaran matematika sekolah dan asesmennya. Dalam Soewandi, A.M., Widharyanto, B., Bram. et. al, Perspektif Pembelajaran Berbagai Bidang Studi. Yogyakarta: USD.

Mawardi, Dona Ningrum. (2011). Komparasi keefektifan pembelajaran matematika dengan pendidikan matematika ralistik indonesia dan problem-based learning pada hasil belajar, motivasi belajar dan sikap siswa SD. Tesis Magister, tidak diterbitkan, Universitas Negeri Yogyakarta, Yogyakarta.

Nur, Tajudin. (2008). Analisis data. dalam bahan ajar cetak. Penelitian pendidikan SD. Dirjen Dikti Departemen Pendidikan Nasional.

Santrock. J. W. (2008). Educational psycology ( $3^{\text {rd }}$ ed.). New York: McGraw Hill Book Company.

Schunk, D.H., Pintrich, P.R., Meece, J.L. (2008). Motivation in education: Theory, research, and applications $\left(3^{\mathrm{rd}}\right.$ ed.). United State: Pearson Prantice Hall.

Shore, E.F. \& Grace, C. (2006). Pintar membuat portofolio : Panduan langkah demi langkah untuk guru. (Terjemahan Fretty H. Panggabean) Jakarta: Erlangga. (buku asli diterbitkan tahun 1998).

Suparno, Paul. (2001). Teori perkembangan kognitif Jean Piaget. Yogyakarta: Kanisius.

Surapranata, Sumarna \& Hatta, Muhammad. (2007). Penilaian portofolio: Implementasi kurikulum 2004. Bandung: Remaja Rosdakarya.

Wibowo, Istiqomah. (2009). Sikap. Dalam Sarwono, S.W., Meinarno, E.A. Psikologi sosial. Jakarta: Salemba Himonika.

Wijaya, Ariyadi. (2012). Pendidikan matematika realistik: Suatu alternatif pendekatan pembelajaran matematika. Yogyakarta: Graha Ilmu.

Zubizarreta, J. (2004). The learning portfolio: Reflektif practice for improving student learning. Bolton: Anker 